\section{Protests over proposed changes}

BRITISH universities last week attacked government policy on higher education in the strongest terms they have yet dared to use. The Committee of Vice-Chancellors and Principals (CVCP) accuses the Department of Education and Science of "gravely underestimating" future demand for university education, while the government "is as a matter of deliberate policy providing for fewer places than would be reasonable even on the basis of its own projections". The committee dismisses the government's declared wish for a further shift toward scientific and technological subjects as representing "a view of society which we cannot accept" .

CVCP's comments are made in its published response to the questionnaire circu-

lated to universities in November by the University Grants Commitee (UGC). The questionnaire asked a wide-ranging series of questions on the possible future development of higher education. But several universities have rebelled and refused to answer a question which asks them to consider the likely consequences of an annual reduction of 1 or 2 per cent in the level of financial provision per student. The University of Aberdeen says bluntly "we cannot usefully be willing accessories before the fact to our own mutilation and we decline to give a detailed response to these destructive hypotheses".

The questionnaire was circulated in response to a request from the Secretary of State for Education and Science, Sir Keith

NIH grants

\title{
Indirect costs under attack again
}

\section{Washington}

INDIRECT costs continue to eat up an increasing share of the research budget at the National Institutes of Health (NIH). And according to a report from the General Accounting Office (GAO), the chief reason is the failure of NIH to audit the indirect cost rates claimed by universities receiving NIH grants.

Indirect costs, a euphemism for overheads, cover administration, depreciation on buildings, services such as libraries and other expenses incurred by the universities as a result of taking on federal research projects. Since 1966, when Congress lifted a restriction that had held indirect cost reimbursements to 20 per cent of direct research costs, the proportion of $\mathrm{NIH}$ money going to indirect costs has steadily climbed, reaching 43 per cent of direct costs in 1983. Some institutions have much higher rates; Harvard University, for example, charges indirect costs at 70 per cent of direct costs.

According to GAO, from 1978 to 1983 $\mathrm{NIH}$ audited the indirect cost claims of only 47 of the 700 institutions receiving grants. Significantly, 40 of those audits (the others contained insufficient details to draw any conclusions) disallowed a total of $\$ 57.8$ million in indirect costs. The unstated implication is that NIH could save hundreds of millions of dollars each year by closer scrutiny of the universities' claims. GAO says that many requests for audits by the government's contract negotiators went unanswered.

NIH officials are said to blame rising indirect costs on the universities' adoption of "sophisticated cost allocation techniques which maximize the amount of allowable reimbursements", but GAO finds that government negotiators in at least some cases allowed huge increases in indirect costs to pass unquestioned. Although negotiation with the universities in general brought about a reduction in the universities' claimed indirect costs, GAO investigators could find no written explanation for the many large increases of the overload rate allowed.

Departmental administration costs have been the hardest to control, as they are based on largely subjective "effort reporting" by faculty members - a declaration of time spent on research (direct costs), administration (indirect costs) and teaching (not reimbursable). Effort reporting has been decidedly unpopular with faculty members, who have complained that it is impossible to categorize their functions and that the exercise thus becomes meaningless. GAO agrees, but its report also notes that the government has virtually no way to verify the universities' claims for departmental costs, which account for 35 per cent of total indirect costs claimed by large universities.

The GAO report is at least the twelfth in as many years to complain about rising indirect costs. None has yet had the least effect. An attempt two years ago by the Reagan Administration to impose an across-the-board 10 per cent reduction in indirect costs was laughed out of Congress, which apparently remains reluctant to cut any part of the NIH budget.

One GAO recommendation that may, however, carry some weight - and which would not require congressional approval - is that NIH should in advance set departmental administration costs as fixed allowances. As things are, small institutions (those receiving less than $\$ 3$ million in direct grants) can opt for such a fixed rate, set at 20 per cent of the salaries and expenses of deans and department heads. Last year, NIH negotiated a similar arrangement with Yale University.

Stephen Budiansky
Joseph, for a "free and wide-ranging" debate. The vice-chancellors and principals are concerned that the debate has been undermined by the apparent removal of the prospect of level funding. Recentlypublished government expenditure plans appear to provide for cash increases that will be well below the rate of inflation. The universities protest that they are now having to turn away well-qualified candidates in far greater numbers than just a few years ago, while expenditure per student has fallen by about 10 per cent in real terms in the past four years.

CVCP believes that financial restrictions have hit research activity in the universities more badly than teaching. Many universities are making strenuous efforts to attract money from industrial companies for applied research, so academics are devoting more of their increasingly scarce time to securing outside sources of finance. But universities remain opposed to any erosion of their cherished right to spend their grant as they wish, although there are differences of opinion among the vicechancellors.

Most are opposed to any extension of "earmarking" of components of recurrent grant for specific purposes. Several independent review bodies have suggested that by this means scientific research might be protected, but CVCP feels that only the universities themselves can provide the necessary flexibility of planning. Dr John Burnett, principal of the University of Edinburgh and a vice-chairman of the committee, says UGC "probably doesn't have any idea" how much individual universities are spending on research, and that no central body could cope with the administration of research in all of Britain's universities.

CVCP proposes that universities should in future make a much more detailed input to UGC's planning. Since the collapse a few years ago of the historical quinquennial system for allocating recurrent grants there has been, according to $\mathrm{Dr}$ Burnett, a lack of dialogue between universities and the grant-giving authority. By providing full information on how they would use their grant, Dr Burnett hopes, universities will be able to ensure a better distribution while retaining their independence.

Most universities continue to support the principle that they should be financed from two separate sources, UGC for general support and the research councils for specific research. And they maintain that there is sufficient diversity within the system to cater for all the demands imposed upon it. Not all universities support the continued existence of UGC, however. The University of Salford, which has earned much of its income from external consultancies since its grant support was dramatically reduced a few years ago, accuses UGC of being "intellectually partial, managerially weak and administratively overstretched"'. Tim Beardsley 